\title{
Reflections on the Evolving Landscape of Social Enterprise in North America.
}

\author{
Marguerite Mendell
}

Concordia University, Montreal

\section{Introduction}

For the many researchers studying social enterprises as they emerge in different countries throughout the world, it is clear that the institutional context determines the nature and role of these enterprises. While they are path dependent and assume varying degrees of social and economic significance that reflect the political culture in which they are embedded, social enterprises are universally presented as innovative responses to poverty reduction and social exclusion. They have captured the attention of policy makers, the media and the academic community that is trying to situate social enterprises and their role in an evolving political economy within national contexts and internationally. Not only do institutional contexts determine the nature of social enterprise, definitions vary both between and within individual countries. This does not always reflect disagreement; rather it reveals the novelty and diversity of this hybrid organizational form that combines social and economic objectives in new ways.

Over the last two decades, research has focused on the shift from a welfare state to a social assistance state to reflect the reduction of state engagement in social provision and collective well-being. The focus on the so-called deserving poor in the United States in the 1980's and 1990's reinforced a new political culture that identified a class of dependent and undeserving poor. The dramatic reduction of social programs in favour of active labour market policies led to the adoption of new policy measures to address poverty. However, the 1990's was also a decade in which numerous initiatives based in civil society demonstrated the capacity of citizens to design community based socioeconomic transformation strategies. As these initiatives assumed increasingly significant roles in many parts of the world through the social and solidarity economy and community economic development initiatives, for example, with varying degrees of engagement on the part of governments, researchers described this evolving relationship between the state and civil society as a "new welfare mix" or a "new economy of welfare". However, these terms miss the more flexible and strategic role that governments have been forced to adopt by implying that an established realignment of state, market and civil society characterizes a new and stable "mix". An "enabling state" better describes this "mix" as a new process of policy formation, that gave greater voice to civil society actors in policy design in many countries. Indeed, this also describes the nature of state engagement sought by civil society actors. For civil society initiatives to take root, they required a more horizontal, flexible and dialogic approach. I believe that this sets the context for the evolving social enterprise landscape in North America and elsewhere. $^{1}$

\footnotetext{
${ }^{1}$ Of course, this has been accompanied by a greater emphasis on the local and regional as the political spaces for this process to occur. Discursive institutions have been recognized for their effectiveness in the literature on industrial districts, for example. Today, they go further to include multi-stakeholder and multi-sectoral spaces of negotiation that are also spaces for learning and transformation, or "institutional reflexivity". "Discussion....is precisely the process by
} 
Social enterprises, at least in the United States, internalize a hybrid mix of public, private and civil society activity, each and all of which are constituent and confluent. Is social enterprise re-embedding the market in civil society through its engagement to generate social wealth, or is it contributing to a process of dis-embedding, as a market-based approach to address societal issues imposes a strategy of commercialization? Simply asking this question demonstrates how difficult it is to capture this phenomenon in a homogeneous "new welfare mix" paradigm that realigns state, market and civil society relations. Not only do national contexts matter, but degrees of marketization or commercialization do as well. Is there a homogeneous North American or even an American model of social enterprise? What is its socio-economic and political impact? What is the role of social actors, of foundations, social movements, community associations, etc? In other words, the question of agency is imperative. Who is driving this process? What is the role of government? How do we evaluate the critical and driving role of foundations in the United States, for example?

This chapter provides a broad overview of social enterprise in the North American context. In examining the literature on social enterprise, one navigates through a lexicon of numerous terms and definitions. Coherent analytical work remains to be done, as many researchers point out (Nicholls, 2008). Much of the existing literature consists of fascinating stories that describe the activities of these enterprises and the people involved. The growing interest in social enterprise and social entrepreneurship in North America has also spawned numerous university programs, especially in the United States that, for the time being, primarily employ case study methodologies in their curriculum. As many of these academic programs include the active participation of practitioners, students have first hand access to these experiences. All of this is contributing to a variegated portrait of new organizational models that cover a large range of organizational forms, from innovative social initiatives to businesses that generate income to enable non-profit enterprises to meet their social objectives.

The multiplication of case studies and their accessibility through numerous publications and websites has raised the urgent need for theoretical and analytical work necessary to better understand the role that social enterprise is playing in contemporary society. As many critics have pointed out, social enterprises are increasingly assuming a significant public role as they demonstrate their capacity to address difficult social challenges that neither the market nor the state are able to meet. As new models of social wealth creation, they provide innovative solutions to community problems that "deliver sustainable new social value” (Nicholls, p.2).

While we are better able to understand social enterprises as a new organizational form, their macrosocial impact is not well articulated. We need to apply "systems thinking” to

which parties come to reinterpret themselves and their relations to each other by elaborating a common understanding of the world". (Gertler and Wolfe, 2004, p. 54). This is important in the context of social enterprises that are defined precisely by the porous boundaries between the public and the private, for example. Writers such as Morgan and Amin prospose an "associational state" or a "reflexive state" that provides strategic leadership but engages in dialogue. We have used the term "enabling state" to capture the need for flexibility as the actual transformation of the state is a long and iterative process, even if its practices reveal new patterns of state management. 
explore the social, political and economic impact of social enterprises. As Alex Nichols and colleagues point out in a recent book, there are important lessons to be learned from social movements theory (Nicholls, ibid). However, this suggests that social enterprises are engaged in collective action processes. How useful is this analysis in the current context if rather than identifiable, networked and mobilized actors, social enterprises are numerous discrete, individual initiatives that engage the market and the state in variable ways? Can we weave these fragments into a systemic analysis that accounts for this variability, but also captures the reconfiguration of relations between the state, the market and civil society that is common to them all?

The question we raise as researchers is whether the cultural specificities of the many countries in which social enterprises now occupy a significant socio-economic and political place are forcing a convergence towards a new global perspective on poverty reduction, social inclusion and socio-economic development. The verdict is still out, but as this chapter will reveal, the North American model of social enterprise, or more specifically the American model, is very influential. That said, research on social enterprises in the United States must be historically situated. Are social enterprises a contemporary manifestation of civil society based initiatives expressed in a new form? If so, placing social enterprise in a larger historical context may alleviate the concern that an American model of social enterprise is being adopted universally. If, on the other hand, social enterprises are distinct from these earlier civil society initiatives such as community economic development initiatives and numerous associational or civic movements in the United States that have successfully put pressure on market actors to meet social objectives, the concern is well founded.$^{2}$ What certainly distinguishes social enterprises from earlier citizen or community led strategies is the predominance of market based strategies and the risk of de-linkage from their social and community contexts.

\section{Asset-Based Approaches to Socio-Economic Transformation in the United States ${ }^{3}$}

The following table published by the Aspen Institute in the United States in 2005, is a useful synthetic and historic portrait of community wealth building strategies designed by enterprising organizations that have implemented new "asset-based and other innovative approaches to solving social and economic problems” (Aspen Institute, 2005).

\footnotetext{
2 The Community Development Corporations (CDCs) developed in the 1960's influenced the development of community based initiatives in Quebec and elsewhere, for example. They demonstrate the capacity of civil society to design strategies for socio-economic development and revitalization. The Community Investment Act (CRA) passed in 1977 in the US., requires banks to engage in community initiatives through direct lending practices. This set the stage for the creation of community development financial institutions in the United States and throughout the world. These are but two of the better known examples of numerous socio-economic associational initiatives in the U.S., that have been and continue to be influential internationally.

3 This term is taken from the Aspen Institute in the United States (Aspen Institute, 2005).
} 
Table 1. Community Wealth-Building Institutions: Key Features and Statistics. United States (Aspen Institute, 2005)

\begin{tabular}{|c|c|c|c|}
\hline Institutional Form & Number (2005) & Assets (2005) & $\begin{array}{l}\text { How it Builds } \\
\text { Community Wealth }\end{array}$ \\
\hline $\begin{array}{l}\text { Community Development } \\
\text { Corporations (CDCs) }\end{array}$ & 4,000 & More than $\$ 1$ billion & $\begin{array}{l}\text { Develops local business, } \\
\text { retail and community } \\
\text { facilities }\end{array}$ \\
\hline $\begin{array}{l}\text { Community Development } \\
\text { Finance Institutions } \\
\text { (CDFIs) }\end{array}$ & $\begin{array}{l}718 \text { (federally certified- } \\
2004 \text { data) }\end{array}$ & $\$ 14$ billion (2003) & $\begin{array}{l}\text { Provides financing for } \\
\text { homeownership and } \\
\text { small businesses in } \\
\text { uder-served } \\
\text { communities } \\
\end{array}$ \\
\hline $\begin{array}{l}\text { Cooperatives and Credit } \\
\text { Unions }\end{array}$ & $\begin{array}{l}\text { Approximately } 48,000 \\
\text { businesses with more } \\
\text { than } 120 \text { million } \\
\text { members }\end{array}$ & $\begin{array}{l}\text { Top } 100 \text { non-financial } \\
\text { co-ops have } \$ 263 \\
\text { billion; credit unions } \\
\text { have } \$ 629 \text { billion }\end{array}$ & $\begin{array}{l}\text { Pools resources to } \\
\text { finance businesses on } \\
\text { "one member, one vote" } \\
\text { ownership model }\end{array}$ \\
\hline $\begin{array}{l}\text { Community Land Trusts } \\
\text { (CLTs) }\end{array}$ & $\begin{array}{l}112 \text { nonprofits with a } \\
\text { combined 6,000 housing } \\
\text { units (2004) }\end{array}$ & $\begin{array}{l}\text { Approximately } \$ 500 \\
\text { milliion }\end{array}$ & $\begin{array}{l}\text { oUses nonprofit } \\
\text { ownership of land to } \\
\text { ensure permanently } \\
\text { affordable housing and } \\
\text { other services }\end{array}$ \\
\hline $\begin{array}{l}\text { Employee Stock } \\
\text { Ownership Plans (ESOPs) } \\
\text { and Employee Ownership }\end{array}$ & $\begin{array}{l}11,000 \text {, with more than } \\
8 \text { million members }\end{array}$ & $\$ 555$ billion & $\begin{array}{l}\text { Anchors wealth locally } \\
\text { by rooting business } \\
\text { ownership in the } \\
\text { community }\end{array}$ \\
\hline Municipal Enterprise & $\begin{array}{l}25,000 \text { (many are water } \\
\text { and sewer companies, } \\
\text { but include other } \\
\text { industries such as city- } \\
\text { owned hotels) }\end{array}$ & $\begin{array}{l}\text { 2,000 public utility } \\
\text { companies alone have } \\
\$ 39.6 \text { billion (other } \\
\text { estimates not available) }\end{array}$ & $\begin{array}{l}\text { Uses local public } \\
\text { ownership to provide } \\
\text { services and generate } \\
\text { non-tax local revenue }\end{array}$ \\
\hline $\begin{array}{l}\text { Non-profit Social } \\
\text { Enterprise }\end{array}$ & $500(2004)$ & More than $\$ 500$ million & $\begin{array}{l}\text { Raises revenue for } \\
\text { community-benefit work } \\
\text { through mission-related } \\
\text { business }\end{array}$ \\
\hline $\begin{array}{l}\text { State and Local Pension } \\
\text { Funds (economically } \\
\text { targeted investments) }\end{array}$ & $\begin{array}{l}\text { Used in some form by } \\
\text { about half of all state } \\
\text { pension funds }\end{array}$ & $\begin{array}{l}43.6 \text { billion ( } 2 \% \text { of state } \\
\text { and local public pension } \\
\text { dollars) }\end{array}$ & $\begin{array}{l}\text { Invests public pension } \\
\text { dollars to earn both } \\
\text { social and economic } \\
\text { returns }\end{array}$ \\
\hline Approximate Total & 90,000 & $\begin{array}{l}\text { More than } \$ 1.5 \text { trillion } \\
\text { in assets - up from less } \\
\text { than } \$ 100 \text { billion in the } \\
1960 \text { 's }\end{array}$ & $\begin{array}{l}\text { Combined strategies } \\
\text { anchor capital and } \\
\text { build wealth in local } \\
\text { communities }\end{array}$ \\
\hline
\end{tabular}

It is useful to reproduce this table here as it situates social entrepreneurship and social enterprise in the United States in a temporal and institutional context. In this way, social enterprise is placed on a continuum of initiatives that, for the most part, have been civil society driven socio-economic innovations to reduce poverty and revitalize communities in decline. They include direct engagement by pension funds, employee stock ownership plans, community based finance and municipal enterprises, to name a few. Taken 
individually, these are examples of democratizing economic instruments to reach the individuals and communities otherwise unable to access these resources. Taken together, they provide a template for societal change, as they required enabling legislation and state regulatory mechanisms to be put in place. ${ }^{4}$ That said, there are two potentially conflicting processes under way. Indeed, social enterprises challenge the conventional wisdom that considers these initiatives as a response to market failure located at the margins of the economy, thus denying their innovative capacity to generate economic wealth. Still, the pressure on non-profits to develop commercial, revenue generating activities to be able to meet their social objectives, is reversing the approach of many earlier socio-economic initiatives outlined in the above table, that emphasized the need to re-embed the market, that is, to make economic instruments more responsive to the needs of communities by designing new tools and strategies. The current accent, however, is on marketizing social services, on profitability, to increase the capacity of non-profits to address "social market failure” through new trading activities. Many will state that this concern is not well founded and that the mix of market and non-market activity that characterizes social enterprises assures their commitment to their social mission.

Moreover, the accent is frequently on individuals and on individual social enterprises. Unlike the community-based initiatives developed in the United States, social entrepreneurship and social enterprise are often decontextualized. That said, researchers in the United States are recognizing the need for a more systemic approach. For example, in a recent interview with Jane Wei-Skillern, professor at Harvard Business School, she insists on the need to move beyond developing business skills for non-profits to design new conceptual frameworks for social value creation and strategies for resource mobilization and networkings. (Harvard Business School, 2008) A historically situated analysis of social enterprise is critical to realize this. Earlier socio-economic experiences based in civil society, demonstrated the need to work horizontally, across social, professional and administrative silos to address economic and social issues simultaneously. This required building alliances and working relationships between activists, financial experts, policy makers, planners and so on. Perhaps the main difference is the marginal place these earlier initiatives occupied in the academy. Courses on community economic development were few and far between, most often integrated into sociology curricula on social movements, for example. These initiatives rarely found their way onto a syllabus in management schools, notwithstanding their impact on low income communities across the United States and their influence internationally. Currently, the business schools in major universities in the United States have designated programs on social enterprise and social entrepreneurship, most often funded by major foundations or leaders in the business community, demonstrating their broad appeal as a social business model. ${ }^{5}$ This is a good thing, as it does challenge the exclusivity of profit driven business strategies taught in business schools.

\footnotetext{
4 I have reproduced this table in its entirety for the purposes that are clear from the text. I do wish, however, to say that the figure for social enterprises (500 in 2004) is not documented. I am unaware of the source. There are no precise aggregate figures for social enterprise as yet as this table will confirm. In fact, the need for comprehensive data is expressed by all who are interested in this issue.

5 Among the leading business schools offering programs on social enterprise or social entrepreneurship are Harvard University, Stanford University, Duke University, New York University, Columbia University, Yale University. No doubt, numerous universities across the United States are including these issues in their business school curricula. I
} 
Today, social enterprise is part of a larger movement that has put pressure on the private sector to behave in a "responsible" manner. Corporate social responsibility and socially responsible investment require the business community to examine its practices. While it is certainly true that this is also a business strategy, given the growing public concern with business ethics, the environment and human rights, it is also true that there is pressure on the private sector to evaluate the impact of their commercial activities on these larger societal issues. Moreover, the emergence of a new economic elite with unprecedented levels of personal wealth has spawned a new class of philanthropists and a new and more strategic approach to philanthropy.

The financial difficulties faced by non-profits to meet their goals is fertile ground for new behavioural, organizational and institutional responses. For example, the new class of rentiers and business leaders is converting large portfolios of personal wealth into investment pools for social purpose ventures, transforming traditional donor behaviour into venture philanthropy; non-profits are transforming their organizations into hybrid social enterprises combining trading activities with social engagement. Institutional change, is for now, a process of iterative modifications that have yet to produce a coherent and identifiable regulatory environment.

\section{Table 2. Behavioural, Organizational and Institutional Transformation}

\section{Conventional}

\section{Transformed/transforming}

\begin{tabular}{|l|l|}
\hline Donations/philanthropy & Strategic/venture philanthropy \\
\hline Non-profit organizations & Social Enterprises (hybridity) \\
\hline Legal and regulatory framework; norms & $\begin{array}{l}\text { New legislation; regulation; accounting } \\
\text { norms (social accounting, for example) }\end{array}$ \\
\hline
\end{tabular}

It is not surprising that social enterprise and social entrepreneurship are on the political, economic, social agenda in the United States, given the failure to attenuate poverty and social exclusion, a growing disillusionment with government and/or an embedded critique of government intervention. But this must not be dis-embedded from its historical context. An ethnography of the current social enterprise movement in the United States explains why this is perceived as "new" and different from earlier experiences. The leadership is new, as is the discourse. Is there insufficient dialogue between old and new actors? There are numerous questions as one explores the evolution and widespread interest in social enterprise in the United States today. Moreover, insufficient attention is paid to the variability of approaches within the United States and to the debates this has generated. What is of great concern for many and certainly

note the larger established universities that have also introduced interdisciplinary programs, combining public policy, for example, with business studies and working collaboratively, as in the case of Harvard and Stanford universities. This innovative program includes the participation of leading figures associated with the rising interest in social enterprise and social entrepreneurship. This program, as most of the others listed, are generously financed by these leaders and the organizations they represent. (See Bloom, 2008). 
distinguishes social enterprise in the U.S. from other countries, including Canada, is the role that foundations are playing in shaping the contours of social enterprise in the United States through their financial capacity to influence the nature, scope and objectives of these enterprises and through their political capacity to influence new policy design. We have already noted their role in funding university programs dedicated to social enterprise and social entrepreneurship. In countries that do not have a tradition of numerous large and wealthy foundations, their role cannot be emulated. Many countries are left with a strategy that advocates entrepreneurship in the absence of funders and with weak welfare states. This is not a good prognosis. This is especially true in the transition countries that are experiencing a shift in foundation culture from donor to investor as well.

\subsection{Social Enterprise. What is it?}

While social enterprise and social entrepreneurship are often distinguished in the literature, they are synonymous in the United States where the former is the institutional expression of the latter. There is debate, however, even among its most ardent advocates who question the new revenue generating imperative imposed on non-profit organizations, emphasizing that the only non-profits that can be fully autonomous are those that are fully endowed (Dees, 2001). A great deal revolves around the new "social business" mix that describes the nature of social enterprise in the United States. Much is at stake as these organizations are now forced to develop commercial capacity, whatever form this may take. Still, perhaps the most important question we must ask is why this new imperative is, for the large part, being embraced so widely.

Many definitions of social enterprises compete in the North American context to describe the nature and level of integration between social programs and business activities (Alter, p.211). Regardless of the definition adopted, all social enterprises develop a mission, operational capacity and the means to manage all stakeholders, including funders (Bloom, p.285). The term “social entrepreneur" was first used in the US in the 1970's, according to Gregory Dees. But it was in the 1980's with the creation of the Ashoka Foundation by Bill Drayton and New Ventures by Ed Skloot that this new vision of enterpreneurship captured the public imagination (Fontan et al, 2008). For Drayton, social entrepreneurs applied their skills to social wealth creation. Ed Skloot responded to the financial difficulties of non-profit organizations by proposing revenue generating capacity through trading activities. ${ }^{6}$ Out of this grew numerous hybrid models of social purpose businesses that are classified by many authors today. While this classification is helpful to deconstruct social enterprise and to separate its various components - a uniform typology does not yet exist, even if many writers now subscribe to the classifications that are available.

Kim Alter, has contributed significantly to our understanding of social enterprise in the United States. Similar to the Aspen Institute's synthesis of citizen based socio-economic initiatives over several decades in the U.S., Alter situates social enterprises historically, emphasizing their current public visibility and appeal as the key feature that distinguishes them from earlier income generating activity undertaken by non-profit organizations and

${ }^{6}$ US federal and state funding to non-profits declined by 23\% in the 1980’s and 1990's. (Johnson, 2000) 
from for profit businesses with a clear social mission. As early as the 1960's in the U.S., non-profit organizations established enterprises to create jobs for those excluded from the labour market. Alter traces the roots of these enterprises to cooperatives, community development corporations, micro credit and fair trade activities in the US and abroad (Alter, 2007, pp.2-4). For example, the Italian "social firm” or “affirmative business” was adopted by many organizations in the U.S. in the 1960's and 1970's, to provide employment opportunities for people with disabilities.

In 1996, long before the current interest in social enterprise, the Roberts Foundation Homeless Economic Development Fund defined social enterprise as "a revenue generating venture founded to create economic opportunities for very low income individuals, while simultaneously operating with reference to the financial bottom line" (Alter, 2007,p.11). NESsT, a non-profit enterprise working in emerging market countries to develop social enterprises that increase the financial sustainability and social impact of civil society organizations, refers to "the myriad of entrepreneurial or 'self financing' methods used by non-profit organizations to generate some of their own income in support of their mission" (ibid). While the first definition applies a "program approach" to social enterprise, in the second, the emphasis is on a "funding approach" (ibid). In response to the need for a broad definition, Virtue Ventures suggests that a social enterprise "is any business venture created for a social purpose-mitigating/reducing a social problem or a market failure - and to generate social value while operating with the financial discipline, innovation and determination of a private sector business”. (ibid) ${ }^{7}$ For Gregory Dees, in his foundational article on the meaning of social entrepreneurship, these are entrepreneurial approaches to social problems. Social entrepreneurs are "change agents" who create social value through innovation, adaptation and learning. They are bold risk takers. Dees resists the social enterprise label that puts pressure on social entrepreneurs to generate revenue through trading activities; this will force "mission drift", a deviation from the objectives and priorities of social entrepreneurs. While social enterprises operate in the market, their social mission must be at the core of their activities.

At the same time as many documents address definitional and conceptual issues, the literature provides numerous profiles of exceptional social entrepreneurs. Their "stories of change" ${ }^{8}$ are also told on videos easily accessible on U-tube and other internet providers. One is struck by the remarkable people who are profiled but more so by the commitment of foundations to widely publicize these experiences. ${ }^{9}$ We have already noted the important role played by a new generation of wealthy individuals that include

\footnotetext{
${ }^{7}$ Virtue Ventures is a small firm that provides research and technical assistance to social enterprise. See www.virtueventures.com. Glossaries and definitions are provided on numerous web sites. An Exploration of Contemporary Meanings of Social Enterprise. www.accord.org.au, Australasian Institute for Social Entrepreneurship; Social Enterprise Alliance Lexicon. www.se-alliance.org; Institute of Social Entrepreneurs, www.socialent.org, among others. (Alter, p.12)

${ }^{8}$ This is the title of a film series created by the Sundance Documentary Film Program and the Skoll Foundation on on social entrepreneurs. www.skollfoundation.com)

9 The larger and better known foundations supporting social enterprise and social entrepreneurship in the United States include: Skoll Foundation, Schwab Foundation for Social Entrepreneurshiip, William and Flora Hewlett Foundation, David and Lucille Packard Foundation, Calvert Foundation, Ford Foundation, W.K. Kellogg Foundation, Kaufman

Center for Entrepreneurial Leadership, Ewing Marion Kaufman Foundation
} 
Bill and Melinda Gates, Jeff Skoll, the founders of e-Bay and Google, some of the better known among this new class of billionaires. Their foundations are complex organizations with numerous divisions and distinct functions that include investment (venture philanthropy) and donations. In this way, these foundations have several means to support these initiatives both directly with finance capital and indirectly through university programs, the internet and other forms of media (Mendell and Nogales, 2008). Interestingly, George Soros, billionaire founder of Open Society and international philanthropist, considers this new network of foundations as a "cross between a foundation and a movement” (Elkington and Hartigan, 2008, p. 68). More important than the sums that are being invested, is the direct influence on this agenda by a small and powerful group of very wealthy individuals. A new generation of wealth, as is often noted in the literature, is steering social change through these activities. Despite the network of foundations that collaborate in a variety of ways, not the least of which is their capacity to generate interest in social enterprise and social entrepreneurship at the Economic Forum in Davos, the enterprises themselves are not networked and continue to represent numerous individual and diverse experiences. ${ }^{10}$

The Social Enterprise Alliance in the United States provides a directory that identifies approximately thirty sectors of activity, the vast majority of which are in services ranging from disaster assistance, health, homelessness and housing, immigration and poverty, civil and human rights, substance abuse, sports and recreation, to name a few. It also includes other community economic development, media and communications, alternative trade and development and the biomedical sector. But social enterprises are primarily located in the social service sector in which non-profits in the U.S., have played a critical role. ${ }^{11}$

There exists no comprehensive data on social enterprise in the U.S. Estimates are drawn by examining Internal Revenue Service (IRS) data, for example. In 2002, close to 200,000 organizations filed as public charities with the IRS in 2002 (Salamon and Sokolowski, 2005). As well, over 100 million Americans are members of a cooperative (Aspen Institute, 2005). Credit unions in the U.S. hold \$629 billion in assets; other forms of cooperatives have a total of $\$ 263$ billion in assets (Aspen Institute, ibid). An additional source is the employment data on non-profit organizations. In 2004, workers (paid and full-time volunteer) earned $\$ 321.6$ billion and represented $10.5 \%$ of the total workforce in the U.S., and 6.6\% of economic activity (Salamon and Sokolowski, 2005) A recent publication by the Social Enterprise Initiative of Harvard Business School, states that there are currently 1.5 million non-profits and other social ventures with total revenues of $\$ 700$ billion in the U.S. They control approximately $\$ 2$ trillion in assets (this includes the large education and health care sectors) (www.hbs.edu/socialenterprise/). While coherent data is still lacking, what is clear according to the authors of this study is that "the social sector is big business in the United States" (ibid). And it is because this "big business" is unable to do its job that social enterprises have arrived on the political, social and economic agenda.

\footnotetext{
10 The Schwab Foundation in Geneva funded the creation of the Economic Forum in Davos. As stated above, it now has a designated foundation for social entrepreneurship.

11 Social Enterprise Alliance, SEA (www.sea.org)
} 


\subsection{Social Enterprise Models}

As stated above, existing literature focuses both on individuals, profiling social entrepreneurs and on social enterprises. Recent publications are responding to the need to classify social enterpreneurship and social enterprise to distinguish their various forms and activities. This will contribute to the much needed work on standardization and coherence that is critical to the development of enabling public policy.

In a recent book on social entrepreneurship, John Elkington and Pamela Hartigan present three social enterprise models : (i) leveraged non-profits; (ii) hybrid non-profits and (iii) social business. Their reference to leveraging applies to the potential sources of funding including philanthropic and government support, business partnerships and income from underserved or untapped markets (Elkington and Hartigan, 2008, pp.30-31). These models can also be classified by their mission orientation ranging from what Kim Alter refers to as (i) mission centric, (ii) mission related and (iii) unrelated to mission orientation in her focus on social enterprises. The following combines the models provided by Elkington and Hartigan and classification by Alter.

\section{Model 1 (mission centric)}

- $\quad$ Meets unmet needs (public goods to most vulnerable with little or no access)

- Entrepreneur and organization are “change catalysts”

- $\quad$ Multiple partners (financial and political support)

- Founding “entrepreneur” becomes “figurehead”

\section{Model 2 (mission related)}

- $\quad$ Meets unmet needs (public goods to most vulnerable with little or no access) but it is possible to earn a profit

- A marketing plan is developed to ease access

- $\quad$ Enterprise can engage in cost recovery through sale of goods and services thereby tapping new markets

- $\quad$ Diversified funding (private, public, philanthropic, including loans, grants, quasi-equity investments

- $\quad$ Increased participation by investors and business creates pressure to move towards Model 3 to access new funding, especially from capital markets

- Raises the risk of "mission drift"

\section{Model 3 (unrelated to mission)}

- Entrepreneur establishes a venture as a business with a social and/or environmental mission

- $\quad$ For profit business model; returns flow to low-income groups and are reinvested in the enterprise to increase the capacity to reach its target population 
Table 2. Mission vs. Profit Motives in Hybrid Organizations (This term captures the three models described above) ${ }^{12}$

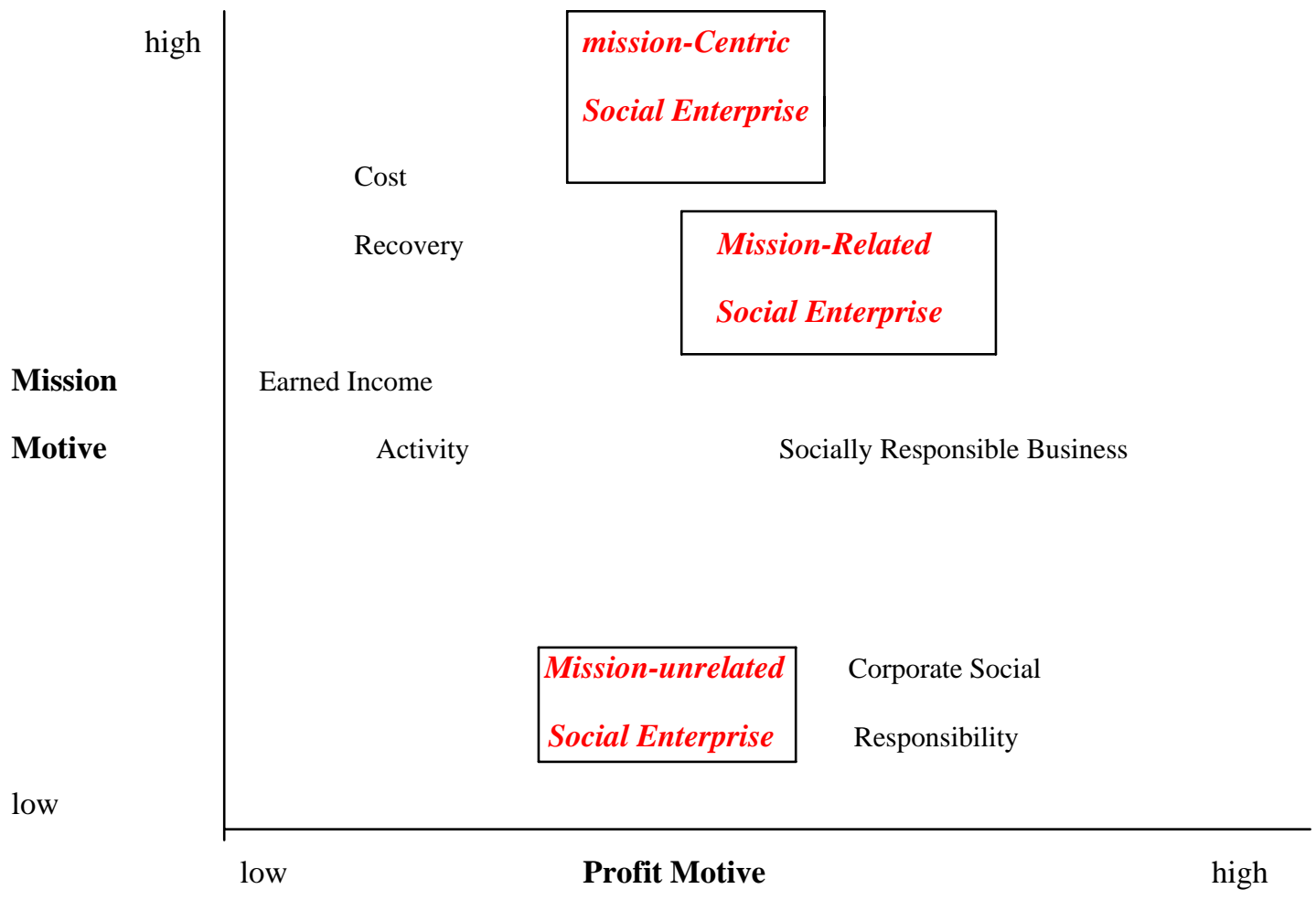

Kim Alter's typology is even more useful as she further explores the hybridity of enterprises that, in many cases, are more complex and combine social and business entities, create subsidiaries and diversify their activities. These are usually characteristic of older, more mature social enterprises that create multi-sector organizations linked through differentiated markets (target populations), creating business ventures to finance their multiple activities. The Council of Community Clinics (CCC) in San Diego is an interesting example of such a hybrid, complex, mixed model. These clinics provide services to the uninsured and the underinsured poor. The CCC, a non-profit organization

\footnotetext{
12 This is taken from Alter, 2007, p. 22. It is a scatter diagram to demonstrate the relationship between the type of organization and its principle objectives or motives. There are examples of each organizational type in the Alter article. I wish to summarize one that I think is particularly interesting and is a mission-related social enterprise. IONA Senior Services is a non-profit organization that created a mission-related social enterprise called Essential Eldercare. While IONA provides numerous free services for the elderly in Washington, D.C., it has created a commercial enterprise, Essential Eldercare, selling upscale, high end services to middle and high income seniors. In fact, it is really their markets which are differentiated and not the services they provide enabling IONA to generate income for its free services and also reaching a larger market of seniors who have the means to pay for these services. Facilities and services are shared between the non-profit IONA and the for profit Essential Eldercare. This is one of several innovative examples of Model 2 social enterprises. Indeed, we ask several questions related to how we define "essential services”. If they are part of the public good, should they not be universally available at no cost, paid for through the tax system? This question is more relevant in Canada and in European countries than in the United States with a minimal welfare state and little, if any, commitment to universality.
} 
focuses on advocacy and lobbies for new legislation. The second entity in this structure, the Community Clinic Health Network (CCHN), a non-profit subsidiary of CCC provides technical support to increase the capacity of community clinics. The third structure, Council Connections, is a wholly owned for profit subsidiary of CCC that purchases supplies and pharmaceuticals in bulk which it then sells to community clinics for profit, but at considerably reduced prices. I note this example in detail because it demonstrates how a non-profit organization can remain at the head of a hybrid, mixed structure that generates income not only to sustain its own activities but to increase purchasing power for low income populations by offering essential goods at reduced prices.(Alter, ibid. p.48) Of course, this begs the question of free access to pharmaceuticals for the elderly. But this example can be presented as a structure with a different set of goods and/or services. $^{13}$

Elkington and Hartigan provide examples of these models by focusing on social entrepreneurs (ibid. pp. 33-43). While Alter includes illustrations of the classification she has produced, the focus is on working through the features that distinguish social enterprises so as to move towards more coherent and standardized definitions of the different models. All three draw upon American and international examples of social entrepreneurship and social enterprise, revealing the extensive engagement of Americans in social enterprise development in the South. In the United States, the stories told provide examples of social enterprises that, in many cases, serve high end markets, generating sufficient income to finance their activities, to expand existing services and to develop new ones. And paradoxically, the declining donations from foundations that was the stimulus for non-profits to explore business strategies, has re-engaged foundations as investors championing these new enterprises.

While the logic has shifted from giving to investing and while a great deal of interest is currently focused on the changing nature of foundations and their capacity both to influence the social agenda and to reinforce disengagement by the state, as we have already noted, in reality their investment of approximately \$100 million annually is, to quote Elkington and Hartigan, “a drop in the bucket” (ibid.,p.80). This suggests that their direct contribution to developing strategies of social inclusion is far less than their potential negative impact on state funding of social programs in the United States and elsewhere through their growing influence.

Access to capital continues to be a critical issue for social enterprises. Regardless of what appears to be a rapidly growing social finance market, much like social enterprises, the capacity to raise capital is most often hindered by the absence of enabling public policy standardization, information, evaluation and coordination. A legal framework for social enterprise does not yet exist (Elkington and Hartigan, p.81). The hybridity, flexibility and novelty of social enterprise is also its Achilles heel. Accessing capital markets and drafting enabling public policy requires basic parameters that are comprehensive.

\footnotetext{
13 The network of non-profit day-care centers in Quebec (Association québecoise des CPE <AQCPE>) has recently created a single buyer cooperative, William, to purchase goods and services for all member day care centers. In this case, the purchasing entity, also a monopsony as in the case of Council Connections in California, is collectively owned, reflecting the commitment in Quebec to retain collective ownership of social enterprises, in the form of cooperatives or non-profit enterprises.
} 
Designing these parameters is a challenge raised throughout the literature. At the macro level and even internationally, important advances have been made in developing new indicators to serve ethical markets, for example. The Global Reporting Initiative, new ethical indexes, carbon exchanges are but a few examples of tools that are being designed to influence the behaviour of corporations and investors internationally. Social accounting, triple bottom line, blended value are terms that are well understood and the basis for a new calculus for social purpose business. In many ways, exploring the literature and information on social entrepreneurs and social enterprise in the United States suggests that these innovations in measurement and evaluation are insufficient to move from individual experiences to a systemic approach. Or, as we suggest, is the absence of direct political engagement the real issue? No one has yet calculated the benefit of this transfer in social responsibility to private initiative. This is necessary to be able to evaluate the impact of social enterprise if it implies, as it does in the American context, a considerably reduced role for government.

\section{Social Enterprise in Canada}

This article has deliberately focused on social enterprise in the United States, given the impact the American vision and experience is having internationally. While social enterprises in other countries reflect their cultural context and are path dependent, the American model has had widespread influence. This is certainly as true for Canada as it is elsewhere, at least through the incorporation of the concept of social enterprise into the public discourse. That said, the distinct political cultures of the United States and Canada create important distances not reflected in their geographical proximity. The culture of individualism that underlies social entrepreneurship, for example, is less present in Canada than in the United States. ${ }^{14}$ Despite a swing to the right in Canada, especially with the recent election of a conservative government but also associated with the former government and its commitment to reduce government spending, cut social programs and introduce active labour market policies, there is an entrenched welfare state culture in Canada that has fought for the preservation of public goods, in particular the fragile health care system that has been under attack across the country in recent years. The Canadian heritage of social citizenship has deep roots, distinguishing it from the United States. Unlike its southern neighbours, citizens in Canada, for the most part, resist the privatization of public services. That said, they are also concerned with accessibility and the deterioration of the quality of these services, two realities that are exploited by critics from the right who argue for an American approach to health care and social service provision more generally.

In a recent literature review on social entrepreneurship in Canada, Sherrill Johnson of the Canadian Center for Social Entrepreneurship at the University of Alberta, one of the few Canadian universities with a designated program, notes the need for research in this area that is, for the time being, largely practitioner driven (Johnson, 2000) ${ }^{15}$. Moreover, there

\footnotetext{
14 For example, almost 30\% of workers in Canada are unionized; over 40\% are unionized in Quebec. This in contrast to about $13 \%$ in the U.S.

15 There are several universities with programs or courses on social enterprise and/or social entrepreneurship in Canada, including Concordia University, Montreal, the University of Toronto, Université de Québec à Montréal, McGill University, Dalhousie University as well as programs on community economic development at Concordia
} 
appears to be less enthusiasm in Canada about social entrepreneurship than in the U.S., except among young people. Johnson confirms our view that this is largely attributable to an embedded welfare state culture and the resistance by the business community to this approach. Johnson also notes the important overlap with community economic development strategies and practices that blur the distinction between these more integrated and collective approaches and the current advocacy for social entrepreneurship in Canada.

Similar to the United States, comprehensive data on social enterprise in Canada does not exist. Nor have definitional debates been fully resolved. For the time being, figures are taken from the Canadian Voluntary Sector Initiative and from data on cooperatives and mutual associations (VSI, 2002). In 2002, there were over 160,000 non-profit organizations in Canada employing 2 million people, generating over $\$ 75$ billion in annual revenue. Input-output analysis of the Canadian economy for this period estimates the total value of services offered by non-profit welfare organizations at $\$ 3.4$ billion and those offered by other non-profits serving households at $\$ 10$ billion. $^{16}$

There are approximately 9,000 cooperatives, 1,000 credit unions and caisses populaires across the country with a total of $\$ 225$ billion in assets and 16 million members (Canadian Federation for the Humanities and Social Sciences, 2006). Approximately 125 mutual associations with $\$ 2$ billion in total assets, cover one million policy holders. Added to this complex portrait are over 3000 community economic development organizations with approximately 3,500 employees and 19,000 volunteers across the country.

\subsection{An embedded social enterprise model}

It is difficult to address social enterprise from a Canadian perspective given the regional diversity of Canada and a variegated political and economic landscape that includes a legacy of social democracy in some of the western provinces, a conservative orientation in the oil rich province of Alberta and shifting political sands in the rest of the country. Today's community based initiatives and social enterprises are rooted in a long history of cooperatives, credit unions, community economic development initiatives, and adult education in many parts of the country. The leaders of the Antigonish Movement in Nova Scotia, laid the foundations for contemporary community based initiatives in the 1920's. In Quebec, today's social economy traces its roots to the establishment of the Mouvement Desjardins, the credit cooperative established in rural Quebec at the turn of the $20^{\text {th }}$ century. These are important illustrations of citizen based socio-economic transformation strategies. It is useful to note some landmark initiatives that were built on these historic experiences.

University, Montreal, the University of Cape Breton in Nova Scotia and Simon Fraser University in British Columbia. Neither the universities nor the programs mentioned enjoy the large endowments by foundations and wealthy benefactors found in the United States.

16 These figures increase significantly with the addition of religious organizations, sports and recreation clubs and nonprofit educational institutions for a total activity of $\$ 21.9$ billion representing $\$ 12.6$ billion in wages and salaries (this is $2.4 \%$ of all wages and salaries in Canada, but they pay close to $60 \%$ of their income in salaries compared to under $25 \%$ for the economy as a whole) (Price Waterhouse). 
In 1976, New Dawn Enterprises, located on the island of Cape Breton in Nova Scotia, established the first community economic development corporation in Canada. As a nonprofit organization dedicated to community development, one could say this was a social enterprise before the term was used and generalized to refer to social purpose or mission driven businesses. However, it is the implementation of a multi-sectoral and multistakeholder comprehensive community initiative for socio-economic revitalization by New Dawn Enterprises from the outset, that is the foundation for what I will refer to as an embedded social enterprise model to distinguish the Canadian model or vision of social enterprise, for the most part. This goes further than the important classification provided by Kim Alter of a mixed or complex model to describe the most hybrid of social enterprises.

From the beginning, New Dawn established numerous place-based integrated initiatives and enabling economic instruments, including real estate, financial and commercial activities, training and social services (www.newdawn.ca).$^{17}$ In fact, the strategy adopted by New Dawn is closer to the American community development initiatives of the 1970's than to the current accent on individual social enterprises and social entrepreneurs. While social enterprises in the United States serve community needs, they most often contribute indirectly to broader development strategies. The focus on self-reliance refers to the enterprise, a non-profit organization that can stand on its own as a social enterprise. While social enterprises in the U.S. are established to address community needs, in most cases, these refer to target populations and are less frequently or less strategically integrated into spatial strategies. In contrast, New Dawn Enterprises and the numerous community economic development initiatives across the country in Canada work towards community self-reliance. I note this to suggest that although social enterprise in Canada shares many of the same the same features as its American counterpart, it is more closely tied to a community or a collective approach to socio-economic innovation, poverty reduction and economic revitalization.

Within Quebec, the first community economic development corporations (CDECs) were established in the early 1980's in urban neighborhoods in Montreal by social activists who responded to the economic crisis of the 1980's by initiating a process of instituted collaboration between the private sector, community organizations, the labour movement and social movements. The depth of the crisis could only be addressed through dialogue and the co-construction of new socio-economic approaches to local development. The CDECs were the seeds of what we now recognize as intermediary public spaces designed by social actors. For example, labour market re-integration through training businesses was facilitated through enabling policy, providing the necessary public support for these enterprises to operate. These training businesses are the precursors of today's social enterprises, given their mandate to address “employability” and social exclusion and not

\footnotetext{
17 New Dawn Enterprises established New Dawn Holdings Limited (NDHL) to increase the capacity of New Dawn Enterprises to create jobs and promote economic initiatives. A legal framework in the province of Nova Scotia considers NDHL a community economic development corporation eligible for tax credits. This is an important illustration of a fully integrated strategy including enabling public policy that describes other community based initiatives in Canada. Today the more common reference to comprenhensive communities initiatives is a term and an approach also borrowed from the U.S.
} 
only job creation. This is but one example of the capacity to innovate in a multistakeholder environment. Many would later interpret such labour market policies as proactive in contrast to the so-called passive assistance programs associated with the welfare state. However, in the context of the evolution of social enterprise in Quebec and Canada, this is an important illustration of policy innovation and realignment of government and social actors. It demonstrates the capacity of government and social actors to co-innovate in the area of labour market policy that is applicable to the numerous other sectors of activity in which civil society organizations are better able to serve the public interest many of which might now be identified as social enterprises. ${ }^{18}$ The CDEC experience illustrates the value added that integrated multi-stakeholder intermediaries bring to addressing complex socio-economic challenges within a public interest perspective enabled by accommodating policy innovation.

The evolution of the social economy in Quebec today and the incorporation of social enterprise into the current discourse reflects an underlying comprehensive and collaborative approach with its roots in community initiatives of the 1980's and to the earlier role of the cooperative movement in Quebec throughout the century. It is not surprising that today's leadership includes many of those who led the community economic development movement in the early 1980's. And so unlike the United States where we noted the importance of integrating social enterprise into the history of earlier initiatives, in Quebec, this history is shaping the current approach to the social economy and social enterprise. The continuity from the early cooperative movement to social enterprise today distinguishes the Canadian experience, I believe. This is largely due to a common vision, a shared commitment to progressive social change. Today, experiences in Quebec, for example, are foundational for current thinking on the social economy and social enterprise across the country.

The diversity of Canada is revealed in many ways, not the least of which is the definitional debate on the social economy throughout the country. Whereas the social economy has common roots in cooperatives and mutual associations, the contemporary social economy in Quebec, an integrated economic model of socio-economic transformation, finds common ground with the community economic development initiatives in the rest of the country. For example, New Dawn Enterprises was a founding member of the Canadian Community Economic Development Network that represents 750 CED organizations across the country today. ${ }^{19}$ The social economy has its own network in Quebec. The Chantier de l'économie sociale is, in fact, a network of networks representing collective enterprises in numerous sectors producing goods and services. Collective enterprises refer to both cooperatives (producer, consumer, worker and most

\footnotetext{
18 The Quebec government established an inter-sectoral labour market advisory board that includes the private sector, the labour movement, social movements and government. It also created numerous sectoral committees to address labour market issues, including one for the social economy and community organizations.

19 The Canadian Community Economic Development Network (CCEDNet) was established with 16 member organizations in 1999. The exponential increase in its membership in less than a decade reveals the importance of community based strategies for economic development across the country. Social entrepreneurship and social enterprise are embedded in these strategies. There are, of course, individual social enterprises as well that serve new and unmet needs of target populations that may not be integrated into a larger developmental strategy. This is often true for urban social enterprise.
} 
recently solidarity cooperatives ${ }^{20}$ ) and non-profit enterprises. It is important to note that non-profit organizations in the social economy are not exclusively providing social services; they engage in the production of both goods and services, distinguishing these from American social enterprise. ${ }^{21}$ Moreover, there are limits here as well. Unlike the U.S. model, community organizations and advocacy groups in Quebec are not under pressure to transform into social enterprises engaged in market activities.

In Quebec, a model of social entrepreneurship and social enterprise is evolving to reflect the embeddedness of these initiatives in organizational or territorial collectivities. The privatization of social services through social enterprise is not a strategy that is advocated. That said, the increasing presence of social purpose enterprises leaves open possibilities for developing markets and commercialization. How this is realized also varies across the country. Community based businesses may be privately owned; in Quebec, social enterprise remains associated with the social economy and its commitment to collective ownership. This is an evolving landscape.

\section{Table 3. Social Enterprise in Quebec (Definition adopted by the Chantier de l'économie sociale ${ }^{22}$}

- Social enterprises emerge from a collective process. It is a business that is both financially viable and socially profitable.

- Social enterprises are collectively owned.

- Governance in social enterprises is democratic and participatory in contrast to the U.S. accent on profit distribution restrictions.

- Social enterprises engage in the production of goods and services. They meet both new and unmet needs; they respond to critical social needs but also to new opportunities and aspirations (new sectors such as social tourism, culture, recycling, communications).

- Social enterprise is located within an intermediate public space - the network of social economy networks - involving public, private and civil society actors

\footnotetext{
${ }^{20}$ Legislation was passed in 1997 establishing solidarity cooperatives that include stakeholders (citizens) as members. These are an adaptation of the Italian social cooperatives.

21 The critical challenge facing actors in the social economy is to press the Government of Quebec to modify the legislation on non-profits that currently considered Part 3 of the Companies Act governing corporations. This creates barriers for these non-profits, not the least of which is their ability to raise capital investment. In the US., legislation has been passed permitting tax deductible status for investment in social enterprise by foundations and in the U.K. the Community Interest Company is an important reference for other countries and regions facing this institutional barrier.

22 The many sectors of activity in the social economy in Quebec include: tourism, culture, housing, agriculture, training businesses (labour force integration); adapted business (for disabled workers), daycare, home care, recycling, new technologies, fair trade, community media, manufacturing, recycling.
} 
Table 4. The Social Economy in Quebec (2002) (most recent data)

-7822 enterprises (3881 cooperatives; 3941 non-profit organizations)

-Business volume without credit unions (caisses populaires)

\$17.2 billion (\$15.9 cooperatives; \$1.3 billion non-profit organizations

-Business volume with credit unions

$\$ 102.5$ billion (\$101.2 billion, cooperatives; $\$ 1.3$ billion, non-profit organizations)

Two recent studies in Quebec interviewed social entrepreneurs as defined by the researchers, since this term is now adopted to refer to leaders in community economic development and the social economy (Fontan et al; Navarro-Flores, Mendell and Lévesque). Not surprisingly, the individuals interviewed share a background of militancy and activism in social movements, community organizations and the labour movement. They have assumed a leadership role in community based economic development, in many cases over several decades, in other cases more recently. They identify with the term social entrepreneurship to name what they have been doing and as a basis to develop networks among themselves. For example, social entrepreneurship clubs are springing up across the province. In most cases, however, these individuals have the support and training provided by intersecting sectoral, inter-sectoral and territorial networks such as the community economic development corporations in Quebec and more than100 local development centers established by the Quebec government in 1997 as part of its decentralization strategy largely influenced and inspired by the CDECs and the Chantier de l'économie sociale. All this to say that social enterprises are not emerging as individual de-contextualized experiences, or less so than the discourse would suggest.

\subsection{A systemic approach to social enterprise}

The above definition in Quebec has influenced debates on social enterprise across Canada. It is increasingly linked with community economic development, community based business and local development strategies. In other words, social enterprise is integrated into a systemic approach to social exclusion, labour market transformation, territorial (place-based) socio-development strategies. This was clearly articulated in a Standing Committee Submission to the federal government in Canada (2006) that also included innovative methods of service delivery and increasing productivity and competitiveness to the list of contributions by social enterprises to Canadian society. While we have outlined many of the differences between the United States and Canada that set the framework for how social enterprises are evolving in these countries, paradoxically, a more integrated approach in Canada has drawn upon important lessons from the United States, in particular the community economic development movement, community-based finance (part of a new financial architecture referred to as social or solidarity finance today) and comprehensive community initiatives. 
The recent networking of social economy and community economic development organizations in Canada is permitting a dialogue that cuts across individual enterprises and territorial or place-based strategies. Policy discussions involve actors and government representatives in a more horizontal dialogue. The links that seem to be absent in the United States, both horizontal across sectors and vertical between different levels of government, is present in varying degrees in Canada. Unfortunately, this is not so at the federal level, where the current government abolished an initiative established by the former government to move in these directions by creating a Social Economy Initiative and a Cities Agenda, two horizontal policy spaces for these issues to be discussed. And so much of the work is at the provincial level for the time being.

\section{Conclusion. Social Enterprise and Policy Innovation in the United States and Canada.}

In Canada, emphasis is placed on the need for a supportive environment for social enterprises that includes the development of markets, enterprise skills, access to capital investment, promoting visibility and enabling public policy. But it also includes the need for intermediary organizations, for cross sector support, which goes beyond the call for networking and resource mobilization in the U.S. that refers primarily to the enterprises themselves. The recognition that intermediaries are critical for social enterprises calls for new public spaces (Enterprising Non-Profits, 2007; Torjman, 2008) where representatives of community organizations and social enterprise, the private sector and all levels of government can meet. Clearly government capacity is limited by jurisdictional responsibility. But as we have seen in Canada, even this can be impermeable if there is political will.

Enterprising Non-profits, a Canadian network of social enterprises, has recently reinforced the need for sectoral intermediaries tied to the specific needs of social enterprises. However, in Quebec, we have learned that for these intermediaries to be effective, they must be designed as coordinated horizontal spaces that can address these needs inter-sectorally. But most important is the increasing recognition of these intermediaries as sites for innovation in public policy. ${ }^{23}$ Such deliberative and dialogic public spaces permit more efficient responses to challenges that these enterprises face, from developing business skills, to raising capital and creating markets. And some public policy initiatives can easily be adopted by all levels of government - municipal, regional and national - such as procurement practices to develop stable markets for social enterprises. ${ }^{24}$ Governments are also urged to recognize the positive outcomes and policy payback from supporting social enterprises through enabling macro policies that reduce

\footnotetext{
23 See especially the examples of Vibrant Communities and Action for Neighborhood Change in Canada both of which are important illustrations of horizontal, multi-stakeholder intermediaries established to address poverty reduction and social inclusion. (www.vibrantcommunities.ca; www.anccommunity.ca)

24 This can be done through various means, including so-called "unbundling” that allows for splitting markets that privilege single or a small number of suppliers, for example (Enterprising Non-Profits, 2007) A social purchasing portal was launched in numerous cities in Canada in 2003 to favour social responsible locally-based business producing goods and services setting a precedent for this type of policy that could be applied to social enterprises.
} 
the burden of government in many areas. ${ }^{25}$

In parts of Canada, notably in Quebec, citizen-based service delivery paid for largely by government is considered a service contract and not a subsidy (except by its political detractors). Citizen based initiatives, including social enterprises, are delivering services in the public interest. These are investments in the public good and not expenditures. Governments have to calculate the social return on these investments. This logic is increasingly well understood for social enterprises and by governments supporting such initiatives, but it is not applied to government itself, where a subsidy logic that interprets such engagement as the price paid for market failure, dominates. I believe that this discrepancy best captures the fragmented and ad hoc manner in which the social enterprise agenda is developing both in Canada and the United States. Although we have identified the sources of difference between these two countries that are establishing the parameters for social enterprise, the growing recognition for conceptual innovation to accompany the behavioural, organizational and institutional innovations underlying social enterprise that we have identified, has yet to produce the much needed transformation of logic in government. While both the U.S. and Canada have introduced policies to accommodate social enterprise, the U.S. with its more characteristic legislative approach and Canada in its more characteristic program approach, these remain within the existing parameters of policy that are themselves determined by deeply rooted perceptions that translate into a calculus bound by fixed categories of income and expenditures. Of course this then leaves little but market failure to explain out of the box support for social enterprises. Indeed, the policy menu is largely predetermined.

Jed Emerson, a pioneer and leading thinker on these issues of social enterprise and social entrepreneurship recently remarked on the growing number of conversations between the business community, social entrepreneurs and various investor groups, concluding that rather than more initiatives and organizations, what is needed are ways to connect these to "leverage individual insight to achieve sustainable, global change" (Emerson, p.404). My own conclusion to these reflections on social enterprise in the U.S. and Canada is that indeed intersecting inter-sectoral networks are critical in both these countries to leverage the numerous initiatives that fall under this new rubric of social enterprise. But the missing piece here, I believe, raises a question Emerson does not ask. If, indeed, the ability for non-profit organizations to achieve their social goals rests on their ability to transform their behavioural and organizational culture and if this is perceived more widely as the most effective "disruptive social justice" strategy for poverty reduction and social inclusion (Nicholls, p. 4xx), for countries like Canada, where social justice remains within the public realm, how can governments maintain this commitment and reconceptualize their own role ? I believe that the cultural legacy of Canada will provide the pressure to keep this question on the social enterprise agenda. The significant place occupied by the social economy in Quebec in society is leveraging both the capacity of other parts of the country to work within their regions and to collectively press for a

25 Former Prime Minister of Canada, Paul Martin, a strong advocate of social enterprise and the social economy is pressing the Canadian government to introduce enabling tax policy for these initiatives citing the U.K. Community Interest Company and the U.S. tax legislation expanding legislation on charitable donations to permit foundations to invest in social enterprises. (Toronto Star, February 25, 2008) 
common policy framework at the federal level. This seems to be the major difference between social enterprise in Canada and the U.S. In Canada, the foundations for an embedded social enterprise model exist that distinguish it from its neighbour to the south.

\section{Bibliography}

Action for Neighbourhood Change. http://www.anccommunity.ca

Alter, Kim (2007). Social Enterprise Typology. Virtue Ventures LLC. 124p.

Alter, Sutia Kim (2008) "Social Enterprise Models and their Mission and Money Relationships" in Alex Nicholls ed. Social Entrepreneurship. New Models of Sustainable Social Change. Oxford University Press. pp. 205-232.

Australian Institute for Social Entrepreneurship. An Exploration of Contemporary Meanings of Social Enterprise .http:// www.accord.org.au

Aspen Institute (2005). Enterprising Organizations. New Asset-Based and Other Innovative Approaches to Solving Economic and Social Problems. www.aspeninstitute.org

Bloom, Gordon M. (2008) “The Social Entrepreneurship Collaboratory (SE Lab): A University Incubator for a Rising Generation of Social Entrepreneurs” in Alex Nicholls, ed. Social Entrepreneurship. New Models of Sustainable Social Change. Oxford University Press. pp.270-306

Borzaga, Carlo and Jacques Defourny (eds) (2001). The Emergence of Social Enterprise. Routledge. 383p.2001)

Canadian Center for Social Entrepreneurship (2001). Social Entrepreneurship

DiscussionPaper. No. 1. 8p. www.ccsecanada.org

Canadian Community Economic Development Network (CCEDNet) http://wwwccednet-rcdec.ca.

Chantier de l’économie sociale. www.chantierdeléconomiesociale.ca

Dees, J. Gregory, “The Meaning of “Social Entrepreneurship”” March 302001. http://www.fuqua.duke.edu/centers/case/documents/dees_SE.pdf 
Downing, Rupert \& Neamtan, Nancy. "Social Economy and Community Economic Development in Canada: Next Steps for Public Policy”. Chantier de l'economie sociale. September 21, 2005.

http://www.ccednet-rcdec.ca/files/Issues\%20Paper_Sept_2005.pdf

Elkington, John and Pamela Hartigan (2008) The Power of Unreasonable People. How Social Erepreneurs Create Markets That Change the World. Harvard Business Press. 242p.

Emerson, Jed, Tim Freundlich and Jim Fruchterman et al (2005). Nothing Ventured, Nothing Gained. Addressing the Critical Gaps in Risk-Taking Capital for Social Enterprise. Skoll Center for Social Entrepreneurship. Working Paper. 24p.

Enterprising Non-Profits (2008). http://www.enterprisingnonprofits.ca

Fontan, J.M., Julie Allard, Anaïs Bertrand-Dansereau and Julien Demers. Enquête auprès d'entrepreneurs sociaux. Réseau québecois de recherché partenarialae en éeonomie sociale (RQRP-ES). Cahiers RQ-03-2007. 103p.

Gertler, M.S., and D.A. Wolfe (2004). "Local Social Knowledge Management: Community Actors, Institutions and Multilevel Governance in Regional Foresight Exercises”. Futures 36 pp.45-65.

Gould, Sid (2006). “Social Enterprise and Business Structures in Canada. Fraser Valley Center for Social Enterprise. www.centreforsocialenterprise.com/documents.html. 94p.

Harvard Initiative on Social Enterprise. www.hbs.edu/socialenterprise

Institute of Social Entrepreneurs. www.socialent.org

Johnson, S. (2000). Literature Review on Social Entrepreneurship. Canadian Center for Social Entrepreneurship. 16p.

Johnson, S. (2003). Young Social Entrepreneurs in Canada. Canadian Center for Social Entrepreneurship. 27p.

Lévesque, Benoît (2002). "Entrepreneurship collectif et économie sociale: entreprendre autrement” Cahiers CRISES. 1-02-2002. 33p. 
Loewen, Gary, Brendan Reimer and David LePage (2008). "Social Enterprise Policy Workshop". National CED Conference. Waves of Change. Building People Centered Economies.

Martin, R.L. and Saly Osberg (2007). "Social Entrepreneurship: The Case for Definition". Stanford Social Innovation Review. Spring. 13p.

Mendell, Marguerite and Rocio Nogales (2008). "Social Enterprises in OECD Member Countries. What are the Financial Streams?” in Antonella Noya (2008) New Frontiers of Social Enterprises. OECD/LEED (forthcoming)

New Dawn Enterprises. www.newdawn.ca.

Nicholls, Alex, ed (2008) Social Entrepreneurship. New Models of Sustainable Social Change. Oxford University Press. 448 p.

Nicholls, Alex and Albert Hyunbae Cho (2008) "Social Entrepreneurship: The Structuration of a Field" in Alex Nicholls, ed. Social Entrepreneurship. New Models of Sustainable Social Change. Oxford University Press. Pp. 99-118.

Nyssens, Marthe (ed) (2006). Social Enterprise. At the Corssroads of Market, Public Policies and Civil Society. Routledge. 335p.

Pearce, John (2003) Social Enterprise in Anytown Calouste Gulbenkian Foundation. 192p

PriceWaterhouseCoopers “Social Enterprise Economics: Report” March 29 2006.

Salamon, Lester M., and O’Sullivan, Richard. "Stressed Out but Coping: Non-Profit Organizations and the Current Fiscal Crisis”. Listening Post Project John Hopkins University: Center for Civil Society Studies. January 19, 2004.

http://www.jhu.edu/listeningpost/news/pdf/comm02.pdf

Salamon, Lester M. and Sokolowski, S. Wojciech “Nonprofit Organizations: New Insights from QCEW Data”. Monthly Labor Review. SEptember 2005. P. 19-26. http://www.bls.gov/opub/mlr/2005/09/art3full.pdf

Schwab Foundation. www.schwabfound.org.

Skoll Foundation. "What is a Social Entrepreneur?"

http://www.skollfoundation.org/aboutsocialentrepreneurship/whatis.asp

Social Enterprise Alliance. www.socialenterprisealliance.org 
Starr, Martha A. (2008). "Socially Responsible Investment and Pro-Social Change”. Journal of Economic Issues. Vo. XLII, No.1. pp.51-73.

Torjman, Sherri (2008) Shared Space. The Communities Agenda. Caledon Institute of Public Policy. 276p.

Torjman, Sherri \& Young, Bill. "Money and Meaning: Blended Value in Community Enterprise”. CAledon Institute of Social Policy. Februrary 2007.

http://www.caledoninst.org/Publications/PDF/615ENG.pdf

Toronto Star (2008). "Linking Profits with Good Works". Editorial. Toronto Star. February 25, 2008. www.thestar.co/article/306164. 2p.

Virtue Ventures. http://www.virtueventures.com

Vibrant Communities. www.vibrantcommunities.ca

Voluntary Sector Initiative. http://www.vsi-isbc.org. 